\title{
The aetiology of childhood obesity: a review
}

\author{
Kimberley L. Procter \\ Nutritional Epidemiology Group, Centre of Epidemiology and Biostatistics, 30-32 Hyde Terrace, \\ University of Leeds, Leeds LS2 9JT, UK
}

\begin{abstract}
Whilst the prevention of childhood obesity is the only viable, enduring, cost-effective solution to the obesity epidemic, effective methods for it remain elusive. Furthermore, strategies to influence obesogenic environments remain relatively unexplored. In order to be able to develop powerful population-level interventions and public health policies to prevent childhood obesity, it is important to understand its aetiology and those environments that are most amenable to measurable change. First, the present paper considers why we should be concerned about obesity in children, from both the perspective of the increased health risk to the individual and the high economic cost of treatment of obesity and related diseases, highlighting why the prevention of childhood obesity is important. Next, the determinants of health behaviour and the obesogenic environment are explored, which helps us to understand why the aetiology is so complex and that potential causal factors should not be considered in isolation, as the interaction between these factors is also important. The paper then considers the multi-factorial aetiology of childhood obesity and the rationale for the increasing trends in obesity that are evident, in order to understand what is changing in society and our children's behaviour that is triggering the positive energy balance leading to obesity. The review emphasises the need for multi-level approaches if we truly want to prevent childhood obesity. It also serves to highlight that there is a need to extend the current research base in order to build a well-founded framework to form the basis of a strategy for the prevention of childhood obesity.
\end{abstract}

Aetiology of childhood obesity: Prevention of obesity: Obesogenic environments

\section{Introduction}

The present review focuses on the increasing prevalence of childhood primary obesity, a condition caused by chronic energy imbalance due to excess energy intake and/or insufficient energy expenditure (as opposed to the rare instances of secondary obesity, which can occur due to endocrine problems (for example, Cushing's syndrome, hypothyroidism) or genetic abnormalities (for example, Down's syndrome, Prader-Willi syndrome) $)^{1}$. What has changed in society and behavioural patterns in recent years to warrant the rapid rise in the prevalence of childhood obesity that is currently evident? Why are children consuming too much energy and/or not taking enough exercise?

The paper starts by briefly considering why we should be concerned about obesity in children - looking at the impact of childhood obesity, both in terms of the child's health and the strain it imposes on the health system. These factors facilitate an understanding of why prevention of obesity in children is so important. Next, the determinants of health behaviour and the obesogenic environment are explored.
Then the review considers whether genetics or the environment are leading the change, before moving on to consider the complex, multi-factorial aetiology of childhood obesity and the rationale for the increasing trends in obesity that are evident, in order to understand what is changing in society and our children's behaviour that is triggering the positive energy balance leading to obesity. Finally the paper draws conclusions about the evidence base for different causes of childhood obesity, in particular considering the importance of the obesogenic environment.

\section{Impact of childhood obesity on health}

Obesity in children, and adults, is a rapidly growing problem in the UK and worldwide and has been increasing at accelerating rates in more recent years. Childhood obesity is associated with a number of co-morbidities in childhood and with an increased risk of adult disease, particularly CVD, hypertension and type 2 diabetes. Also obese children tend to be more isolated and have lower self-esteem than their peers ${ }^{2}$.

Abbreviation: SES, socio-economic status.

Corresponding author: Dr Kimberley L. Procter, fax +44 113343 4877, email k.procter04@leeds.ac.uk 
Reducing childhood obesity and health inequalities is at the centre of the UK government's health policy. The government's 'Choosing Health' white paper on improving public health in England ${ }^{3,4}$ outlines a number of actions to tackle key current public health issues. Specifically, six key priorities for action have been identified, with children's health, particularly childhood obesity, being a major focus. Halting growth in childhood obesity is their prime objective. One of the steps towards achieving this is the development of a national social marketing strategy. Health-related social marketing is 'the systematic application of marketing concepts and techniques, to achieve specific behavioural goals, to improve health and reduce inequalities, 5 . Importantly this process addresses short-, medium- and long-term issues, recognising that encouraging healthy choices and associated behavioural change is a complex process, requiring more than merely increased public awareness of health issues. This shows how government public health policy is moving away from considering disease groupings in isolation, towards a population approach that considers the determinants of health which is why obesity has suddenly risen up the agenda.

Obesity-related diseases account for a substantial proportion of costs of healthcare resources worldwide ${ }^{6}$. The UK Select Committee Report on Obesity ${ }^{7}$ estimated that the total cost of treating obesity in the UK was $£ 3.3-3.7$ billion in 2002 and will increase to $£ 7$ billion by 2020. As well as being expensive, the treatment of obesity is time consuming and ineffective. Plus obese children are more likely to become obese adults ${ }^{8,9}$, with all the corresponding health and social disadvantages. Whilst recognising that the treatment of obesity is also an important approach that needs to be addressed concurrently with prevention approaches, prevention of obesity is likely to be more cost effective than treatment ${ }^{6}$. Without a focus on prevention, the unavoidable exorbitant cost of managing the obesity epidemic will almost certainly be too expensive for many countries. Accordingly it follows that the prevention of obesity in children is key.

The importance of the environment in controlling obesity is widely acknowledged. A WHO report ${ }^{10}$ states that major social and environmental changes to make healthier choices more accessible and preferable are required to prevent obesity. The strength of an environmental approach is that significant population benefits can result from even fairly small effects if a large number of individuals are exposed to that environment ${ }^{11}$.

Yet whilst the prevention of childhood obesity is the only viable, enduring, cost-effective solution, effective methods for it remain elusive. Furthermore, strategies to influence obesogenic environments remain relatively unexplored. In order to be able to develop powerful population-level interventions and public health policies to prevent childhood obesity, we need to fully understand its aetiology and those environments that are most amenable to measurable change, which is what the present review seeks to consider.

\section{Determinants of health behaviour}

Various models have been proposed to facilitate the understanding of the complex, multi-factorial aetiology of childhood obesity and to identify the role of broader environmental influences (obesogenic factors) on energy balance, including: ecological systems theory ${ }^{12}$, the epidemiological triad ${ }^{11,13}$ and the ecological model ${ }^{14,15}$. Similarly, Flodmark et al. ${ }^{1}$ suggest, without the use of a model, that there are six levels that should each be considered when addressing a preventative programme for childhood obesity.

Each of these models concurs that the determinants of obesity sit at many different levels, and agree that successful prevention of obesity needs to work at all of these levels. However, it is how these levels are defined and summarised that varies between the models. For example, the ecology model in Fig. 1 considers the multiple levels of influence (both within and outside the individual) on the determinants of health behaviour, seeking to address the complex web of behaviours that impact an individual's dietary and physical activity choices. Accordingly this model subdivides the influences on obesity health behaviours into three broad categories: individual factors, social and cultural factors, and the physical environment.

Individual factors include the knowledge, attitudes and beliefs of the individual.

Social and cultural factors include, for example, the impact of the influence and behaviours of friends, family, peers, neighbours, and all rules (whether formal, for example, laws, regulations, policies, or informal, for example, institutional rules, including in the home) on the eating and physical activity behaviours of the individual. On a micro level, this encompasses the 'culture' or 'ethos' of a school, home, workplace or neighbourhood. On a macro level, this includes the media's impact on influencing the socio-cultural aspects of food and physical activity, particularly through advertising and marketing.

The physical environment category looks at what is available. It includes, for example, food and physical activity choices that may be impacted by climate, geography and crime rates (both perceived and actual), as well as nutrition and exercise expertise, available technology, and food labelling. This category would also encompass financial factors, including both costs and incomes for consumers, money spent on the promotion of healthy lifestyles by health departments, advertising by fast-food outlets and government funding of roads, public transport and recreation activities.

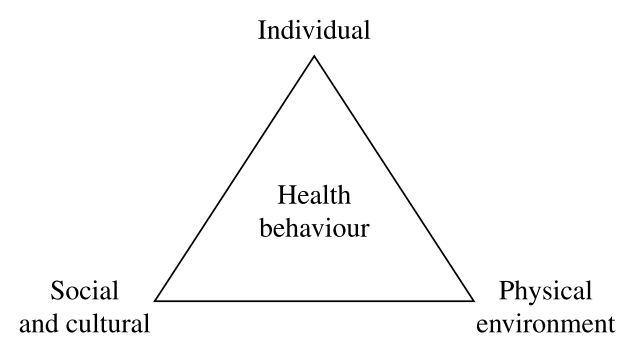

Fig. 1. The ecological approach states that health behaviour is influenced by more than just individual factors (such as attitudes, beliefs and knowledge). Factors outside the individual (i.e. social and cultural and the physical environment) also impact on the choices individuals make in relation to health behaviour, as does the interaction between the individual and these external factors. 
This model suggests that health behaviours can be changed by impacting factors other than at the individual level. For example, if crime rates were lower, parents may allow children to play outside more frequently, increasing child physical activity levels and reducing the risk of obesity. Consequently, interventions to reduce obesity in children would be more effective if targeted at multiple levels of influence of the determinants of health, rather than solely focusing on the child.

It is also important to note that the interaction between these categories means that different individuals will be influenced by different environmental factors, or in different ways by the same environmental factors. For example, an individual with a high income level may not be influenced by fluctuations in the price of food, yet lower-income individuals may be easily influenced by such fluctuations and consume less of the produce, such as fruit and vegetables, when it is higher priced. This makes interpretation very difficult and also means that the interaction between multiple obesogenic factors needs to be considered rather than just a single obesogenic factor in isolation.

\section{Genetics or the environment?}

The regulation of energy balance and the aetiology of obesity are enormously complex, with numerous genetic, hormonal, neural, metabolic, behavioural, societal and obesogenic influences ${ }^{16,17}$. Many studies show a strong genetic link with obesity. That is, an individual is more likely to be obese if he/she has obese relatives. For example, adoptees' BMI were more similar to biological parents' $\mathrm{BMI}^{18}$ and weight gain in twins showed a genetic factor ${ }^{19}$. However, the environment has to be, at least partially, responsible for the rapid rise in obesity, as evidenced by the following:

(1) The fact that the rise in childhood obesity has been so rapid suggests that environmental factors rather than single gene defects are the primary cause (if the cause were genetic then the increasing prevalence would take longer, as it takes time for gene defects to pass between generations).

(2) Migrant studies suggest a strong influence of environmental factors on obesity rates, as migrants have higher BMI than their counterparts still living in the country of origin ${ }^{20,21}$. Also immigrants' offspring have higher rates of obesity than their parents ${ }^{21}$ and second-generation children have higher obesity rates than first-generation children ${ }^{22}$.

(3) As developing countries switch to more Western diets $^{23}$ and reduced physical activity levels ${ }^{24}$, the prevalence of obesity in children is rising ${ }^{25,26}$. Developing countries also show over- and underweight children in the same family ${ }^{27}$. Both of these instances imply that it is not genetic factors but environmental factors that are influencing levels of obesity.

The difficult question of how much of the variation in obesity is explained by each of genes and the environment has been addressed by Allison et al. ${ }^{28}$. This review suggests that about $10 \%$ of the population may become overweight even in a leptogenic environment and another $10 \%$ would remain slim even in an obesogenic environment. These individuals have strong genetic predispositions to be obese or slim. The remaining $80 \%$ of us possess 'thrifty' genes, which evolved to help us deal with periods of famine and feast and which have not adapted to the modern obesogenic world, where energy-dense foods are readily available and energy expenditure can be minimal. So, for the majority of us, although we possess the genes to become obese (genetics is the loaded gun), it is the obesogenic environment that is the primary factor causing obesity (the environment pulls the trigger).

\section{Aetiology of primary childhood obesity}

So what, exactly, is causing the increasing prevalence in obesity that we are seeing? The answers to the questions regarding the causes of the increased prevalence of childhood obesity remain subject to debate, with different authors holding different opinions and studies producing conflicting results. It may be that there is not a simple or exact answer, particularly as obesity is a condition that develops slowly (so the time lag could mask the causes) plus its cause is likely to be multi-factorial with many confounding factors. Nevertheless, the debate around the reasons for the increasing prevalence of childhood obesity includes the following possible explanations: the present review will look at how physical activity or inactivity affects obesity, dietary risk factors for obesity and then at various obesogenic environments.

\section{Aetiology of primary childhood obesity: physical (in)activity levels}

There is some evidence, particularly in the USA and the UK, of a reduction in habitual energy expenditure in children: reduced walking and cycling, and increased use of cars ${ }^{29}$; increased use of automated transport and technology in the home with more passive leisure pursuits ${ }^{30}$.

A systematic review of studies looking at the relationship between physical activity in children and obesity found roughly half had found no effect and the balance had a negative effect (i.e. increased physical activity levels were protective $)^{31}$. A stronger link has been found between lifestyles characterised by lack of physical activity and excessive inactivity (particularly television viewing) with an increased risk of obesity ${ }^{32}$. It should be noted that physical activity can be measured in a number of ways. Either energy output can be directly measured using calorimetric methods or indicators of energy expenditure (such as the incidence or prevalence of specific physical activities) can be used. Alternatively, physical inactivity can be measured as an indicator of low energy expenditure. Television viewing and/or media time (for example, surfing the web, playing video games, etc) are often used as a proxy for all sedentary leisure activities and so for physical inactivity.

Accordingly many cross-sectional and prospective studies have looked at the association between television viewing and childhood obesity. Some only found a weak association $^{33,34}$, but most found a positive association (after adjusting for potential confounders, such as maternal 
overweight, previous overweight, family structure, ethnicity, socio-economic status (SES) and maternal and child aptitude test scores) in children all over the world - USA ${ }^{35}$, Mexico $^{36}$, native Canadian groups ${ }^{37}$, Australia ${ }^{38}$ and the $\mathrm{UK}^{39}$.

A prospective study by Gortmaker et $a l^{40}$ showed a strong positive dose-response relationship between time watching television and prevalence of overweight (as measured at the end of the 4-year study). This relationship was found after adjusting for potential confounders, including baseline maternal overweight, previous overweight, family structure, ethnicity, SES and maternal and child aptitude test scores.

The effect of television viewing on obesity may be mediated through one or more of the following factors: (1) a reduction in physical activity levels ${ }^{38}$, (2) an increase in energy intake whilst viewing (particularly snacking on energy-dense foods and poor portion control) ${ }^{38,41}$, (3) a reduction in $\mathrm{RMR}^{32,42,43}$, (4) inappropriate food choices due to television advertising for foods high in added sugars or fat $^{44,45}$, and (5) television programmes or advertisements may confuse or contradict the message about a healthy lifestyle ${ }^{46}$.

\section{Aetiology of primary childhood obesity: diet}

\section{Increased energy intake}

It would seem logical that the rise in obesity prevalence might be partly due to increases in energy intake, but paradoxically, in the USA at least, while the prevalence of obesity in adolescents has doubled ${ }^{6}$, energy intakes (in adolescents) have apparently decreased ${ }^{47}$. There are, however, concerns about the accuracy of measures relying on reported food intake. Food disappearance data suggest that energy intakes have actually increased while reported food intakes show a decrease ${ }^{48}$. (Food disappearance is equivalent to food available for consumption. It is calculated by adding total food production (plus imports, minus exports) and net losses from processing at the mill level and food fed to animals. Food disappearance data are a reasonable approximation in all countries of the trends in food consumption at the national level. However, the data do not reflect actual consumption because additional losses in the food chain linking the producers and mills to the consumers are not considered.) Also energy balance is the important factor, so the rise in obesity may be due to energy expenditure decreasing by more than the fall in energy intake.

\section{Eating patterns}

Changes in dietary patterns and eating habits are likely to be factors related to the increased prevalence of childhood obesity.

Snacking is gaining prominence as a potential risk factor for obesity ${ }^{49-52}$, as is skipping meals. Whilst babies and young children characteristically eat frequently, as children get older frequent eating is traditionally (in Western society) replaced by 'three square meals a day'. However, eating occasions are increasingly becoming less well defined and a 'grazing' or snacking culture is permeating our society with 'meals' at more frequent or irregular intervals ${ }^{53}$ and meals being skipped.

The impact of snacking may be attributed to the types and amounts of foods eaten as well as the frequency of eating. Snacking is often associated with more energy-dense foods (and drink) or more total food ingested, particularly outside the home where the types of foods commonly consumed as snacks are often high in fat or high in carbohydrates ${ }^{51}$. It has been shown that body weight is not affected by the frequency of eating - in a laboratory under isoenergetic conditions. However, real life is not isoenergetic. Marmonier et al. $^{54}$ demonstrated that snacks delay the next meal slightly but that the 'snacking individual' consumes more total energy over the course of the day. This suggests that snacking contributes to positive energy balance, over the short term at least. Longer-duration studies, which may be more predictive of long-term behaviour, show inconsistent results. Johnstone et al. ${ }^{55}$ showed no difference in energy intake between snackers and non-snackers over $7 \mathrm{~d}$, whereas Blair $^{56}$ showed higher weight loss in subjects who stopped snacking. A study of children in Japan showed that snacking was correlated with an increased risk of obesity ${ }^{49}$, but a longitudinal study by Phillips et al. ${ }^{41}$ found no relationship between obesity and the consumption of energy-dense snacks.

However, snacking can be difficult to measure as it is often self-reported, which can be highly inaccurate. For example, Barkeling et al. ${ }^{57}$ validated self-reported food intake with saliva tests, which showed significant differences in levels of sugary foods consumed between the obese and non-obese groups, yet the food diaries showed no significant differences.

Children who skip breakfast may have a higher risk of subsequent obesity ${ }^{58,59}$. The mechanism is unclear, but it may be due to breakfast consumption being a marker of general good healthy behaviour or being related to decreased fat intake and decreased snacking during the day. Alternatively, it may be due to an uneven distribution of energy intake over the course of the day, for example, those who do not consume breakfast tend to eat a large amount of food in the evening, and this imbalance could lead to a higher risk of obesity ${ }^{60}$.

Also meal times as a family are becoming increasingly uncommon. This has the effect of fewer social controls on eating and opportunities to observe good role models, which can lead to unhealthy eating habits.

Portion sizes of foods and meals are also gaining prominence as a potential risk factor for obesity ${ }^{61}$. Research has shown that very young children have innate control of appetite and energy balance is achieved, but as children age social and environmental factors take precedence over this biological mechanism ${ }^{62,63}$. In light of this and of the increases in standard portion sizes seen both inside and outside the home in recent years ${ }^{64}$, more research is needed to look at the impact of portion size over a long duration (rather than just one meal) and also the factors that influence this and cause the overriding of our natural biological appetite-control mechanism.

Psychological factors also play a key role in the development of childhood obesity. Increased depression 
and boredom in this age group can lead to comfort eating and binge eating, which are associated with an increased risk of obesity.

\section{Diet composition}

Dietary composition may be an important risk factor for obesity. The amount of fat and type of fat may be important, in part due to the energy provision of fat. Cross-sectional surveys of diet indicate that on average children's intake of fat is close to recommended levels, but that there are big between-children variations in intake levels ${ }^{65}$ and they also show that higher fat intakes (as a percentage of energy intake) are associated with higher weight ${ }^{66-68}$. Energy density may also be important. A UK-based cross-sectional survey showed high-energy-dense diets in young children tend to be higher in fat and lower in sugar content than lower-energy-dense diets ${ }^{69}$, although other longitudinal studies have less clear results ${ }^{34,70,71}$. 'Healthy' food intake and fruit and vegetable intake are negatively associated with obesity ${ }^{10}$, although potential confounding issues, such as deprivation, should be considered. Refined carbohydrate foods, and particularly those with a high glycaemic index such as sugar-sweetened soft drinks, biscuits and cakes, may be associated with obesity. High-glycaemic-index foods increase postprandial blood glucose concentration and so play a part in appetite regulation.

\section{Consumption of unhealthy foods}

Another dietary risk factor for obesity, unsurprisingly, is a high consumption of unhealthy foods, and in particular 'fast' foods and soft drinks.

The popularity of fast foods has increased over recent years and consumption by children has risen $300 \%$ over the last 20 years $^{72}$. It has been shown that when children eat fast food, then that day their energy and fat intake is likely to be higher, and fruit and vegetable intake lower, than normal ${ }^{73}$. Also, children who eat fast food frequently consume more total energy, more energy per $\mathrm{g}$ food, more total fat, more total carbohydrate, more added sugars, and less fibre, less milk, fewer fruits and vegetables than children who eat fast food infrequently ${ }^{73,74}$. Accordingly it is not the consumption of fast food, per se, that leads to obesity (as both lean and obese children consume fast food), but the fact that overweight consumers of fast food are less likely to adjust their daily energy intake to take account of an energy-dense fast-food meal than their lean counterparts ${ }^{75,76}$.

There has also been a massive increase in the amount of soft drinks consumed. Soft drink intake now accounts for the largest single source of non-milk extrinsic sugar intake in young individuals ${ }^{65}$. These fluids tend to replace milk and $\mathrm{Ca}$ intake for adolescents, which is a concern, not least because there is an inverse relationship between $\mathrm{Ca}$ intake and adiposity ${ }^{74}$. Sugar-sweetened soft drinks can lead to increased energy intake, as their energy value is often not differentiated from the energy of solid food. In a study where children were given either a sugar-sweetened or aspartame-sweetened soft drink with a standardised meal, both groups consumed similar amount of foods, resulting in the sugar-sweetened group consuming more energy in total $^{77}$. Furthermore, a prospective study by Ludwig et al. ${ }^{78}$ has shown that the consumption of soft drinks is positively associated with obesity in children (over 19 months) ${ }^{78}$. Although this observational study cannot prove causality, the regression models did take other dietary and lifestyle differences into account to minimise the impact of confounding on the results, but obviously other unaddressed factors could be at work. Furthermore, a longitudinal study over 10 years $^{41}$ also found an association between soda consumption and $\mathrm{BMI}^{41}$. A recent cross-sectional analysis ${ }^{79}$ appears to contradict these findings, with no association found between total amount of beverage consumed and weight status of the child, and whilst higher beverage consumption was associated with total energy intake (positively) it was not related to BMI. However, this study considered very young children ( $2-5$ years), which may be too young to see the long-term impact of higher energy intake due to beverages, plus it is limited by its snap-shot cross-sectional nature.

\section{Aetiology of primary childhood obesity: obesogenic environments}

An obesogenic environment considers the combination of factors that influence health behaviour and is one that makes obesity more likely to occur. It is defined as 'the sum of influences that the surroundings, opportunities or conditions of life have on promoting obesity in individuals or populations $^{15}$. Six different obesogenic environments are now considered.

\section{The fetal environment}

Birth weight is positively associated with childhood obesity, with an increased risk of obesity for both the heaviest and lightest babies ${ }^{31,80-82}$, independent of $\operatorname{SES}^{83,84}$ and gestational age 85 , but may be confounded by maternal weight ${ }^{86}$. However, other studies suggest that subsequent obesity may actually be independent of fetal growth (birth weight), instead suggesting that unfavourable conditions in the fetal environment are fundamental to the increased risk of subsequent obesity.

Maternal diabetes during pregnancy results in offspring with an increased risk of developing childhood obesity ${ }^{87}$. These infants are likely to be born overweight, revert to normal weight by 12 months, then become overweight or obese as older children ${ }^{87,88}$. This higher risk of subsequent obesity is independent of birth weight and maternal weight, suggesting that the effect is due to the unfavourable fetal environment.

Maternal smoking during pregnancy is also associated with an increased risk of childhood obesity ${ }^{89}$. There is a dose-dependent relationship between the number of cigarettes smoked during pregnancy and the extent of childhood overweight or obesity, after accounting for potential confounders (social class, maternal weight and birth weight) ${ }^{90}$, which may be due to programming of appetite regulation ${ }^{91,92}$. There was no association with smoking after pregnancy, suggesting that it is the intrauterine exposure that was fundamental to the increased risk of obesity. 
Maternal fatness may promote childhood obesity ${ }^{81,86}$. Furthermore, studies of famine during pregnancy ${ }^{93,94}$ again suggest that it is the adverse fetal environment rather than any effect on fetal growth that may be responsible for this relationship with obesity.

\section{The infant environment}

There is strong evidence that the environment in early life can determine the risk of subsequent obesity. Contrary to the previous section, Kinra et al. ${ }^{95}$ suggest that the critical period when obesity risk is acquired is postnatally, rather than prenatally.

Postnatal weight gain (of the infant) is thought to be important in determining the risk of subsequent obesity, although the exact 'high-risk pattern' of weight gain is controversial. Rapid weight gain during the first 4 months increases the risk of subsequent obesity ${ }^{84}$, as does rapid weight gain during the first 12 months $^{39}$; also children in the highest age-standardised weight quarter at age 8 and 18 months are at higher risk ${ }^{39}$. Conversely it is suggested that it is the mixture of fetal and infant growth that is important. That is, there is an increased risk of obesity for low-birthweight babies who show catch-up growth or rapid childhood growth $^{39,86,96}$.

Further studies suggest it may be the age of adiposity rebound that is crucial. The evidence is strong that the earlier this occurs the higher the risk of subsequent obesity in the child ${ }^{31,39}$. However, the mechanism for this relationship is unclear and it is undecided whether the association between early adiposity rebound and subsequent obesity is caused by a biological mechanism or whether it simply reflects a child's predisposition to gain weight easily (as a result of existing genetic or environmental circumstances). It does not appear to be due to high early protein intake ${ }^{97}$.

A systematic review by Baird et al. ${ }^{98}$ concluded that the highest risk of subsequent obesity was for infants both at the highest end of the distribution for weight or BMI and those who grow rapidly during infancy. The mechanism for greater fatness earlier in childhood leading to an increased risk of subsequent obesity is unclear. It could be because early excessive fatness predicts earlier maturation (at least after 3-4 years of age $)^{31}$ and early maturation is associated with an increased risk of obesity ${ }^{99}$. However, adolescents who mature later have higher protein and energy intake as well as higher activity levels, which might be the factors that prevent the obesity rather than the timing of maturation itself $^{100}$.

There is evidence for and against the protective effects of breast-feeding. It has shown a dose-dependent (better protection with longer duration of breast-feeding) reduction in the risk of subsequent childhood obesity $90,101-104$, although more recent studies have shown no or limited protective effect ${ }^{105,106}$. Furthermore the designs of the studies with protective effects have been called into question $^{107}$. That said, a fairly recent systematic review found that breast-feeding had a (small) protective effect against subsequent childhood obesity ${ }^{108}$.

The apparent protective effect may be due to confounding variables such as maternal diabetes, maternal BMI, maternal smoking during pregnancy, low birth weight, familial dietary patterns or social class ${ }^{90,109-111}$. Alternatively, the conflicting results may be due to an interaction between breast-feeding and potential confounding factors. For example, Reilly et al. ${ }^{39}$ found that breast-feeding amongst non-smoking (during pregnancy) women was significantly associated with a reduced risk of obesity in the child at age 7 years. This effect was not evident in women who smoked during pregnancy. Without this stratification there was no significant relationship between breast-feeding and obesity.

The mechanism for the proposed protective effect of breast-feeding may be due to the timing of weaning, as solid foods increase the energy density of the diet and so could lead to excess energy intake and consequent weight gain. It might also be a factor of the amount of protein in the diet, with bottle-feeding and early weaning increasing protein intake (breast milk provides a relatively high amount of energy from fat), which may reduce the age of adiposity rebound and increase the risk of subsequent obesity ${ }^{112}$. Feeding style may also be important to the infant's risk of obesity. A 'vigorous' feeding style ${ }^{113}$, restrictive patterns causing upset to the baby ${ }^{114}$ and a lack of control over the child's intake ${ }^{115}$ have all been associated with subsequent obesity.

Sleep duration (as an infant) has been shown to have a negative independent association with the risk of childhood obesity $39,116,117$. There are several different possible mechanisms for this effect. It may be due to growth hormone secretion being altered by the duration of sleep or because sleep reduces the child's exposure to obesogenic factors, such as evening food intake or it could be a marker for another variable, such as levels of physical activity (more active, more sleep required).

\section{The family environment}

It has been shown that family structure, including the family $\operatorname{size}^{58,118}$, birth order of the child ${ }^{119}$ as well as whether it is a single- or joint-parent family ${ }^{58}$ may have an effect on childhood obesity. However, relatively few studies have been undertaken and the results are inconsistent ${ }^{31,120}$.

Parent-child interactions, the quality of the home environment and the level of care provided within a family might also be affecting the behaviours related to the risk of obesity. These factors may have more of an impact on the risk of obesity than family structure or deprivation. For example, children with low cognitive stimulation are at an increased risk of subsequent obesity ${ }^{121}$, as are children who suffer parental neglect ${ }^{122}$.

Parenting styles and behaviours may influence the food and exercise choices of a child. Each member of the family acts as a role model for the child, their behaviour reinforcing and supporting the development of diet and activity behaviours $^{123}$. The family members all share the same environment, which may encourage overeating or a sedentary lifestyle ${ }^{31,124-126}$. Dietary and activity behaviours have been shown to 'run' in families ${ }^{123}$, primarily due to shared environmental factors rather than genetics ${ }^{127}$, and parental diet and activity patterns can predict the risk of obesity $^{123}$. 
Parental BMI (particularly maternal) has a strong positive association with childhood obesity ${ }^{34,121,128}$. This predictor is much stronger with young children ${ }^{129}$, and also if both parents are obese ${ }^{124,130}$. This latter increase is systematic with two lean parents having the leanest children, two obese parents having the fattest children and children of one lean and one obese parent falling in between ${ }^{39,131}$. This relationship is largely due to lifestyle factors, and parents' diet and activity patterns can be used to identify obesogenic or non-obesogenic family clusters, with children in an obesogenic family cluster having a higher risk of obesity ${ }^{123}$.

It is also worth noting that parents of overweight children tend not to recognise that their child has a weight problem ${ }^{132}$. However, this was a small study with a sample of only eighty-three parents. Plus, the recognition scale, used to determine the parents' perception of how overweight (or otherwise) their child was, tends to produce a normal distribution, whereas the actual BMI percentiles of the children in this sample do not appear to be normally distributed. Accordingly we might expect to see greater differential between the perceived and actual child weights at the heavier end of the scale in this study. Nevertheless a subsequent, larger, longitudinal study ${ }^{133}$ using a five-point scale questionnaire to determine parental perception of overweight also found that most of the overweight children (and one-third of obese girls and a half of obese boys) were judged by their parents to be of normal weight. These authors suggest that possible reasons for parental low recognition of a child's weight problem may be due to simple denial, an unwillingness to admit that there is a problem or even desensitisation to overweight because this state has become normal.

Ethnicity could also be important. In the West, non-white children are more likely to be obese than white children; however, this is largely to do with socio-economic differences, such as parental education and family income $e^{121,134-137}$. However, the fact that obesity-related diseases (such as type 2 diabetes or high blood pressure) are more common in individuals from the Indian subcontinent and that the risk of obesity-related complications commences at lower BMI for these populations has implications for childhood obesity in these populations - and more research is required into this ${ }^{120}$.

\section{The school environment}

The schools' policy to promote healthy eating (and/or national guidelines) may affect obesity levels. That is, the choice of foods available during the school day and the types of foods permitted for classroom events may have an impact on obesity rates. The availability of vending machines in schools is associated with an obesogenic environment, although not all the evidence supports this view $^{138}$. Children who attend breakfast clubs consume more fat and saturated fat than children who do not attend ${ }^{139}$. Children who bring a packed lunch to school consume a less healthy meal than those eating school dinners ${ }^{140}$. Externally available foods (i.e. local shops and children being allowed off school premises) may also have an impact on food choices.
School food policies that reduce availability of high-fat and high-sugar foods are connected with reduced buying of these items ${ }^{141}$. However, a recent study by Gould et al. ${ }^{142}$ of school meals in the UK found that two-thirds of schools did not meet the government nutritional guidelines and deprivation was associated with the worst food provision and most unhealthy food choices. This suggests that nutritional standards in isolation do not facilitate healthy eating in schools. Enforcement of the guidelines as well as a pricing policy to encourage healthier food choice (or restrict unhealthy choices) is required to improve the nutrient intake of schoolchildren.

Also, nutritional and physical education might help to reduce the risk of childhood obesity, by promoting healthy eating habits and body image as well as providing opportunities for regular exercise.

A study in primary schools in Leeds used a populationbased approach to implement a health-promotion programme to prevent risk factors for obesity ${ }^{143}$. Positive changes were seen in school meals, tuck shops, and playground activities and the implementation of the programme was a success, yet only nominal behavioural changes were seen in the children ${ }^{144}$. A national programme launched in Singapore to promote healthy lifestyles, 'trim and fit', used similar methods to the Leeds study, as well as giving special attention to overweight children ${ }^{145}$. Conversely, in Singapore obesity levels have fallen since the commencement of the programme, although this may be due to factors outside of the programme. Similarly school interventions have been run to affect children's activities outside of school. For example, Robinson ${ }^{146}$ ran an intervention aimed at reduced levels of television viewing which resulted in a positive association between children's changes in levels of television viewing and adiposity. However, often children return to baseline after the intervention stops.

It has been shown that primary schoolchildren are more active at the weekend than on school days, so although schools are well placed to help tackle childhood obesity, school attendance actually limits levels of physical activity ${ }^{147}$. That said, the level of timetabled physical activity at primary school does not affect the overall daily amount of activity undertaken by the child, as they compensate out of school ${ }^{148}$. Furthermore, although children who walk to primary school expend more energy on that journey than children who are driven, there is no difference between the two groups in total weekly physical activity levels. Again, children are compensating elsewhere ${ }^{149}$.

Low achievers at school are more likely to become obese, although it is not clear whether the poor performance leads to obesity or vice versa ${ }^{150}$.

\section{The neighbourhood environment}

There are many different aspects of the neighbourhood that may have an impact on levels of childhood obesity, for example:

(1) The availability of public transport affects diet and exercise choices individuals make, for example, with where to do the shopping, what to do with the children, 
etc. This impact is obviously larger on families without a car.

(2) Food deserts are areas where there is low (or no) access to affordable, healthy food, particularly if the residents do not have access to a car or good public transport links. This may impact on the dietary choices of residents.

(3) It may be that proximity to or access to parks and green spaces has an effect on obesity in children by impacting on their physical activity levels (for example, playing on swings) or diet (for example, consuming ice creams and sugary drinks), although the little research that has been undertaken in this area tends not to show a relationship $^{151}$. It is likely that perceived neighbourhood safety is a more important determinant of childhood obesity, but again the evidence is con$\operatorname{trary}^{152,153}$.

(4) Crime, both perceived and actual, can affect a parent's decision whether to let the child outside to play, as can road-safety issues, such as safe road crossings, pavements and the speed of traffic ${ }^{151}$.

Deprivation is commonly associated with obesity, although the relationship is not straightforward, depending on the timing of the outcome measure of obesity (that is, whether it is in childhood or adulthood). Also different authors use different measures of deprivation, ranging from a simplistic single indicator of SES as a proxy for deprivation to a more sophisticated indicator of deprivation by ranking several different factors.

A thorough review in 1999 by Parsons et al. ${ }^{31}$ found a relationship between low SES in childhood and subsequent adulthood obesity, which concurs with subsequent work by Hardy et al. ${ }^{154}$ and Okasha et al. ${ }^{155}$, both using father's occupation as the indicator of childhood SES. This relationship was also shown more recently and using a more sophisticated indicator of deprivation (a ranking of three different factors - education level, occupation of head of household and current employment status) ${ }^{156}$. This 'SES of origin to subsequent adult obesity' relationship may be due to: (1) confounding by parental body size (which insufficient studies have considered ${ }^{31}$ ) and (2) SES acting as a proxy for the effect of multiple adverse childhood circumstances, which are then manifesting as adult obesity in the long term ${ }^{157}$. For example, it has been shown that there is a higher density of fast-food outlets in poorer areas, which may (partially) explain the phenomenon ${ }^{158}$.

The 1999 review $^{33}$ did not find any relationship between childhood SES and childhood obesity, although conversely several recent studies have found that children with lower SES or more deprived backgrounds do have an increased risk of childhood obesity. Some studies have used only a single indicator of SES as a proxy for deprivation. For example, household income has been shown to be a significant predictor of childhood obesity (inverse relationship) ${ }^{121,159}$. Similarly, using entitlement to free school meals as a proxy for income ${ }^{160}$, Cecil et al. ${ }^{160}$ found that it was not that these deprived children weighed more than their more affluent peers, but that in fact the higher BMI was due to shorter height, suggesting possible nutrition-related growth restriction in low-income families. Also, children from families with lower education levels have a higher risk of obesity ${ }^{128,161,162}$. However, this effect could be mediated by confounding factors, such as low income and lower levels of cognitive stimulation ${ }^{121}$. Other studies have considered multiple SES factors as an index of deprivation. For example, studies using the Townsend deprivation score (an index score based on a combination of adult unemployment, household size, and car and home ownership) have shown that children from more deprived areas have a higher risk of obesity (despite lower birth weights $)^{95,163}$. However, if the deprivation index is based on the electoral ward of the school (rather than the home), no relationship with childhood obesity is present ${ }^{164}$.

The increased prevalence of obesity in children from more deprived backgrounds could be due to a multitude of factors:

(1) dietary differences are often apparent;

(2) no safe play area for the child;

(3) lack of opportunity and funds for activities, so television viewing is the primary leisure activity by default;

(4) food deserts (lack of accessible, affordable, healthy (low-energy-dense) food);

(5) constraints on energy per $£$, which focuses purchases on energy-dense foods.

Also, whilst deprivation is commonly associated with obesity, affluence has been less critically considered, yet there may also be a link. Certainly early work in Asia found such an association ${ }^{165-167}$, although this could reflect cultural differences that are not prevalent in Western society (that is, whether fatness or thinness is more highly regarded).

\section{The macro-environment}

The macro-environment relates to those influences on childhood obesity outside of our direct control - in particular, industry, media and government.

Industry. This aspect of the macro-environment largely encompasses all levels of the food industry, from manufacture to retail outlets to eating out. However, also included is price and availability of goods that reduce our energy expenditure. It encompasses many different issues, such as hidden fats and/or sugars in prepared foods and greater availability of energy-dense foods, increased use of restaurants and fast-food outlets, larger portions of food offering better 'value' for money, poor labelling of foods, subsidised 'bad' foods as loss leaders and expensive 'good' foods, more frequent and widespread food-purchasing opportunities, and cheap and easy access to labour-saving devices and cars.

It has already been discussed that a high dietary fat intake is associated with obesity ${ }^{66-68}$ and that high fruit and vegetable consumption is negatively correlated ${ }^{10}$. Additionally the rise in soft drink consumption has already been highlighted $^{65}$. Furthermore, sugar consumption in general (including sugar, maize sweeteners, honey and other edible syrups, excluding non-energy sweeteners) has also increased substantially over the last 20 years, largely due 
to increased high-fructose maize syrup use in beverages, bakery products and processed and prepared foods ${ }^{168}$. On top of this, advances in technology have increased the availability of processed and prepared foods ${ }^{169}$. Accordingly, it follows that consuming a diet composed of a large quantity of processed and prepared foods with high 'hidden' fat and sugar content (consumption of which has increased in recent years) may lead, perhaps unwittingly, to increased energy intake and so to obesity. Similarly a diet high in energy-dense fast foods will also lead to increased fat consumption and higher energy intake, which may increase the risk of obesity as well ${ }^{73,75,76}$. Accordingly the fact that both eating out generally and fast-food consumption have increased in recent years ${ }^{72,170}$ should be of concern. Spending on eating in the home is now less than eating out spending ${ }^{171}$. Furthermore, high fast-food outlet density in an area is negatively associated with SES, which in turn is considered a social determinant of obesity with, generally, a negative association between obesity and $\mathrm{SES}^{158}$.

Another factor contributing to increased energy intake, and thus highlighted as a plausible risk factor for obesity, is larger portion sizes ${ }^{76,172-174}$. This factor relates back to industry as the macro-environment because most processed and prepared foods have seen rises in the standard portion size over the last 20 years ${ }^{64,175}$, as have restaurant and fastfood outlet portion sizes. The fact that many packaged foods contain multiple (not single) servings, and that consumers do not recognise this, exacerbates this problem ${ }^{176}$. As well as increasing energy intake on the eating occasion (of the product or at the premises), this may also have a knock-on effect of increasing the expected portion size, or that considered appropriate, at a self-serve eating occasion ${ }^{177}$. This occurrence of 'portion distortion' varies for different foods but does show significant differences (mostly increases) in self-serve portion sizes over the last two decades $^{178}$.

The question of food labelling is frequently discussed as a means to facilitate healthy food choices by the consumer. In the UK, the Food Standards Agency has proposed a 'traffic light' food-labelling scheme in this regard. Whilst several retailers have agreed to introduce it on their own products, many other retailers and manufacturers are introducing their own labelling systems, which only serves to add to consumers confusion. Consumers have been shown to change their consumption patterns depending on the information given about the fat content of the food ${ }^{179}$, although whether this translates into long-term purchasing and consumption patterns remains to be seen. The evidence of providing dietary information about restaurant meals is hampered by the fact that few restaurants provide this facility, particularly at point of purchase ${ }^{180}$, and it has been shown that consumers largely ignore or do not correctly understand restaurant food labelling ${ }^{181}$.

Poor access to affordable, healthy food is considered to be a contributory factor to poor diet and obesity. Whilst the price of food in real terms has reduced, this is largely for 'unhealthy' (energy-dense, high-fat, high-sugar) foods ${ }^{169}$ and it has been shown that these 'food deserts' do exist $^{182-184}$. Improving access to food can increase fruit and vegetable intake, which also suggests that limited access to healthy, affordable food does affect the diet consumed $^{185}$. Also Sturm \& Datar ${ }^{186}$ found that higher fruit and vegetable prices were positively correlated with change in BMI. Yet all the evidence does not agree, as some authors have not found a positive relationship between amount of fruit and vegetables consumed and food deserts ${ }^{187,188}$, although the evidence does seem to be stronger in the $\mathrm{USA}^{189}$. A clear way to increase healthy choices over unhealthy choices is to provide an economic incentive by, for example, healthy food subsidies and unhealthy food taxes. It was shown that young individuals do respond to this, with price rises reducing purchases of a particular food, and substitution between healthy and unhealthy foods occurring as prices rise or fall depending on the amount of disposable income ${ }^{190}$.

Obesity is also promoted by industry in the macroenvironment by the more frequent and widespread foodpurchasing and -consuming opportunities that currently exist. An extensive range of tasty, reasonably priced foods are accessible almost ubiquitously ${ }^{172}$. On the other side of the coin, increased access to labour-saving devices and use of cars has reduced levels of physical activity ${ }^{30}$, which is further impacted by less habitual energy expenditure ${ }^{29,30}$.

Given the food industry's role in encouraging, or at least facilitating, obesogenic behaviour, accordingly they also have a role in preventing obesity. They could reduce the availability of high-fat, high-sugar and energy-dense foods. However, realistically this is not going to happen, as it would be too directly damaging to profits. More pragmatically, food companies could make more (in quantity) healthy and, importantly, cheap products available (rather than making these products a high profit margin alternative). Clear food labelling would also help. Finally, a more indirect role could be taken, with encouraging consumers to select healthy produce and to collaborate in research to increase our understanding about food and health ${ }^{191}$.

Media. There is a broad and strong impact of the media, both negative as well as positive. An example of the positive impact the media can have is the recent success of a UK television chef in bringing the public's and government's attention to the poor diet given to children in schools, leading to changes in awareness of the issue as well as real changes. Food television advertising, especially that aimed at children, is a classic example of a negative impact of the media particularly as this is often for unhealthy foods ${ }^{192,193}$, which can lead to unhealthy food choices ${ }^{44,45}$. Additionally advertisers often concentrate on building brand loyalty and 'creating lifelong customers rather than generating immediate sales, ${ }^{194}$, which means any resulting unhealthy food choices will be enduring. Furthermore, television programmes and advertisements may confuse or contradict the message about a healthy lifestyle ${ }^{46}$. Advertisers refute the claim that they contribute to the obesity problem, stating that they cannot compel individuals into buying goods ${ }^{195}$. However, that response is illogical - if the adverts are not successful why would advertisers go to huge lengths and expense to build brands and advertise products? Excessive amounts of money are spent on advertising (especially when compared with governmental budgets for healthy food promotion). Also a review of the ecological evidence 
showed that there is a significant relationship between television advertising and prevalence of overweight children $^{196}$. All in all this suggests that in this day and age where obesity is a growing problem, television advertising aimed at children should be limited, which probably needs to occur at a governmental level as voluntary codes are largely unsuccessful.

Government. It is all well and good saying that diet and exercise are down to individual choice. But this approach is not working, as demonstrated by the rising prevalence of obesity. Furthermore, in relation to children, their cogitative ability is not sufficiently developed to enable them to take the future consequences of their actions into account when evaluating what to do. Whilst it can be argued that parents therefore have a role in deciding what foods and how much exercise their children should take, arguably there is also a role for government to help children (and their parents) to make healthier choices ${ }^{169}$. Similarly as the market is not providing sufficient, clear, information to allow consumers to make rational, healthy, choices, as demonstrated by foodlabelling confusions, then this also fuels the debate for more heavy-handed government intervention.

If the fact that obesity is associated with increased morbidity and mortality is insufficient by itself to justify bringing obesity on to the government's agenda to take action to reduce, then maybe the economic implications tip the balance. The healthcare costs associated with obesity are increasing and are projected to grow rapidly (as discussed earlier). If prevention measures are not successful then these costs will need to be borne somehow (i.e. by the taxpayer $)^{169}$. Furthermore, the costs of obesity are lopsided. On the one hand, even assuming the consumer has full information about the benefits of physical activity and a healthy diet as well as the detrimental health consequences of obesity, there will still be some individuals for whom an obesogenic lifestyle has the lowest 'cost' (in terms of time, opportunity costs, and money) and so this is their optimal choice $^{197}$. However, it is not an optional choice from a national viewpoint because, on the other hand, the taxpayer bears much of the monetary cost of obesity ${ }^{197}$. Accordingly it follows that there is a role for the government to intervene.

The fact that industry sells energy-dense, high-fat, highsugar foods and energy-saving and sedentary-behaviour devices, such as cars, television sets and play stations, is not good reason for government intervention in the market. They sell these foods because there is demand for them. If consumers demanded healthy products then these would be provided - the strength of the diet industry reflects this. However, the food industry is not 'playing fair'. They have used complicated marketing and advertising practices to increase the amount individuals eat, whilst at the same time (in the USA at least) lobbying government bodies responsible for providing dietary advice to consumers to ensure the message to reduce their energy intake does not get across ${ }^{198}$. These aggressive sales tactics are at least partly due to overproduction of food leading to intense competition to win sales ${ }^{199}$. This sales competition takes place through new or improved products, increased portions, health claims, advertising, and campaigns at special groups such as children ${ }^{199}$, all the while aiming to increase prices as well as sales volumes. Furthermore, government subsidies have facilitated the increased manufacture of cheap, high-fat and -sugar snacks and drinks $^{200}$. Industry (i.e. agriculture, food production and retail, restaurants, diet, pharmaceuticals) does not benefit if society were to eat less ${ }^{199}$. Accordingly they strongly lobby government to ensure little (or no) action is taken to discourage overeating ${ }^{199,201}$, as there would be serious economic consequences for them if obesity reduced. In view of this lack of fair play, industry cannot be relied upon to comply with any voluntary codes of practice to reduce obesity and obligatory policies that need to be established. However, the obesity issue is highly political. The (potential?) conflict of interest between governmental funding and influences from food companies and the government's responsibility to protect the public need to be borne in mind. This leads to a 'policy paradox' whereby governments support the food industry as well as making lifestyle recommendations to maximise population health ${ }^{200}$ and has led to governments taking action contrary to best practice for consumer health and more akin to helping boost food companies' balance sheets ${ }^{202}$.

Litigation also has a role to play in protecting public health, particularly when government policy is non-existent or insufficient ${ }^{203}$. A classic example of this is with the tobacco industry. Whilst a move towards the prolific litigation culture of the USA is perhaps not desirable, nevertheless litigation can help to increase public awareness of the issue and to improve self-regulation of industry, eventually restraining those practices that are detrimental to consumers. For example, leading food companies need to rework their merchandise and marketing methods because, with the obesity issue, potential lawsuits are likely to include "unfair and deceptive trade practice'203. Indeed, it was the wrongdoings of the tobacco manufacturers, rather than the health risks of tobacco, that resulted in successful litigation against tobacco companies ${ }^{203}$. The food companies consider litigation a very real threat, as demonstrated by their attempts to try to prevent it from being allowed ${ }^{204,205}$.

At the present time, turning around public perception of the acceptability of overeating and sedentary behaviour leading to obesity might seem an impossible task. Imagine changing social norms about the (un)acceptability of using a car for a short journey rather than walking. However, so too was changing attitudes to smoking and drink-driving a seemingly impossible task, but both have been very successful (albeit not entirely eliminated). It is argued that the only way we will see a radical reduction in obesity rates is to implement radical policy changes, to regulate food production, marketing and consumption ${ }^{206}$. This view was corroborated in a recent debate at the International Conference of Obesity held in Sydney where there was an overwhelming majority in favour of a more 'heavy hand' of government than that which currently exists across many different countries. Regulation can transform an environment in an instant ${ }^{207}$. It could be used to create leptogenic environments, in the same way that we now have smoke-free environments and clean water ${ }^{206}$. But is there the political will to do what is necessary to fight obesity? There are many conflicts of interest. 
There are many possible government interventions that may help to prevent obesity. It is important that policy does not solely focus on changing individuals' behaviour, but that it also looks at the role of industry and the media in order to make changes at these levels as well.

In relation to the impact of television and physical activity on childhood obesity there are several suggestions. Ban (or at least more heavily regulate) advertising of unhealthy foods aimed at children, especially in schools and on television ${ }^{170,201,206-209}$. Additionally any food advertising to children that is permitted could be taxed, with the proceeds being used to fund healthy lifestyle initiatives and education $^{207}$. Proactively, public service announcements could be shown during children's programming to promote healthy eating and physical activity ${ }^{210}$. Changes to the physical environment may also help to prevent obesity ${ }^{207}$. More pavements, less parking, more 'park-and-ride' schemes, more parks, etc, may all promote a more active lifestyle.

The school environment is an important influence on children. Accordingly it may be helpful to ban unhealthy products from school vending machines (or even a total ban) ${ }^{170,201,207-209}$. Clear, enforced, nutritional guidelines for healthy school dinners are required ${ }^{201,207,209}$, whilst providing the schools with the tools required to prepare these meals. The implementation of healthy eating schemes may also be beneficial. For example, in the UK, there are several such schemes, including the new Healthy Start Scheme, the continuation of the National School Fruit and Vegetable Scheme, and Food in Schools as part of the Healthy Schools Initiative. Compulsory physical education and nutrition classes in schools may also make a difference to the obesity epidemic ${ }^{207}$. The nutrition classes should include how to read food labels, as this will facilitate healthier food choices. This obviously also necessitates clear nutrition labels to be provided by the food industry $^{207,208}$, which probably needs legislation to ensure it happens in a coordinated, comprehensible manner.

Whilst the use of tariffs or import bans cannot be used to control consumption due to the implications on global trade ${ }^{200}$, this does not prevent the use of taxes to tackle obesity. A 'fat tax' could be put on unhealthy (energy-dense, high-fat or high-sugar) foods, which could fund, at least in part, these obesity-prevention strategies ${ }^{170,201,206,209}$. Whilst this is often dismissed as a 'stealth' tax on the poor, if an economic viewpoint is taken, then it is suggested that no amount of increased education or clear nutritional information will change the dietary and activity choices some individuals make ${ }^{197}$, in which case financial incentives (or disincentives) are required. Also, deprivation is strongly correlated with obesity, with an unhealthy diet being an inexpensive $\operatorname{diet}^{211}$, so there is an argument to implement policies that have a larger effect on low socioeconomic groups. A similar tax could be levied on products that promote sedentary activity ${ }^{209,210}$. The other side of this coin is to change the way agriculture subsidies work to reduce the retail costs of fruit and vegetables and to discourage, rather than support, the marketing of obesogenic foods ${ }^{204}$.

Given the tripartite conflict of interests between consumers, industry and governments, which initiatives will be more successful, a supply-side stance (such as restricting food advertising) or on the demand side (healthy eating education) or a combination of both ${ }^{170}$ ? Also, can these initiatives work given the existing influential economic and agriculture policies?

\section{Conclusion}

From both the perspective of the increased health risk to the individual and the high economic cost of treatment of obesity and related diseases, it is important that we preferentially prevent obesity from occurring, whilst nevertheless implementing treatment programmes in parallel as current rates of obesity are already high and we cannot ignore these patients. However, going forward, prevention will be more effective in children, as obese children tend to become obese adults and it may be that behavioural patterns that determine obesity are set in childhood.

The present review has also looked at the different levels of behaviours leading to obesity, which helps us to understand why the aetiology is so complex and that potential causal factors should not be considered in isolation as the interaction between these factors is important. Many studies have looked at simple, single or bivariate, relationships with obesity, rather than considering the multiple factors that actually comprise the aetiology of childhood obesity and considering their inter-relationship and their relative importance. If we do not understand how these factors interact, or the relative strength of different obesogenic factors, we cannot predict the outcome for any one individual.

The present review of the aetiology of childhood obesity considered physical activity, diet and various obesogenic environments. Strong predictors of obesity were found to be high amounts of sedentary time, snacking, skipping meals, portion sizes, energy density of foods and meals and potentially a high sugar consumption. Also various obesogenic environments may be impacting on a child's risk of obesity.

Unfavourable conditions in the fetal environment are a risk factor for subsequent obesity. Infant postnatal weight gain can follow a high-risk pattern - a warning sign for subsequent obesity is when a child is becoming increasingly fat when his/her peers are generally showing a reduction in fatness (i.e. between about 6 months and 5 years old), plus if this fatness is developing when other children are tending to decrease fat it is probably a warning of persistent obesity ${ }^{120}$. Breast-feeding may have a protective effect, although this may be due to confounding variables such as maternal diabetes or BMI. Similarly, longer sleep duration seems to be protective, but may be a marker for other factors.

Parental BMI has a strong positive association with childhood obesity, and familial similarity in behaviour can predict the risk of obesity. The literature supports the view that low SES and/or deprivation in childhood in the home environment is associated with childhood obesity as well as subsequent obesity in adulthood. However, many studies take a too simplistic approach to defining deprivation and insufficient consideration of possible confounding factors, such as parental BMI. Also the school environment may 
influence prevalence of obesity, although the evidence is weaker, but nevertheless schools can be used as a platform to help prevent obesity. Developments in industry, stemming from economic growth, serve to enhance consumption and are aspired to by developing countries, yet are contributing to our obesity problems. Government-led regulation and industry self-regulation can help to level this playing field, albeit many conflicts of interest exist. Further, the extensive, robust impact of the media cannot be ignored.

The present review emphasises the need for multi-level approaches if we truly want to prevent childhood obesity. It also serves to highlight that there is a need to extend the current research base in order to build a well-founded framework to form the basis of a strategy for the prevention of childhood obesity, in particular to be able to address measurable, changeable, environments in order that viable, long-term, population-level prevention strategies can be successfully implemented.

\section{Acknowledgements}

The present study was supported by funding from the ESRC and MRC. Thanks also to Professor Janet Cade, Dr Joan Ransley and Professor Graham Clarke for their comments on the drafts.

\section{References}

1. Flodmark C-E, Lissau I, Moreno LA, Pietrobelli A \& Widhalm K (2004) New insights into the field of children and adolescents' obesity: the European perspective. Int $J$ Obes 28, 1189-1196.

2. Strauss RS (2000) Childhood obesity and self-esteem. Pediatrics 105, e15.

3. Department of Health (2004) Choosing Health. Making Healthy Choices Easier. London: Department of Health.

4. Foster RK \& Buttriss J (2005) A review of the Public Health White Paper. Nutr Bull 30, 70-75.

5. National Social Marketing Centre, (2006). It's our health! Realising the potential of effective social marketing. Summary, independent review, findings and recommendations. http://www.nsms.org.uk/images/CoreFiles/NCCSUMMARY ItsOurHealthJune2006. pdf (accessed 30 April 2007).

6. World Health Organization (2000) Report of a WHO Consultation on Obesity: Preventing and Managing the Global Epidemic. WHO Technical Report Series, no. 814. Geneva: WHO.

7. Select Committee on Health (2004) House of Commons Health - Third Report. www.parliament.the-stationeryoffice.co.uk $/ \mathrm{pa} / \mathrm{cm} 200304 / \mathrm{cmselect} / \mathrm{cmhealth} / 23 / 2302 . \mathrm{htm}$

8. Guo SS, Roche AF, Chumlea WC, Gardner JD \& Siervogel RM (1994) The predictive value of childhood body mass index values for overweight at age $35 \mathrm{y}$. Am J Clin Nutr 59, $810-819$.

9. Freedman DS, Khan LK, Mei Z, Dietz WH, Srinivasan SR \& Berenson GS (2002) Relation of childhood height to obesity among adults: the Bogalusa Heart Study. Pediatrics 109, E23.

10. World Health Organization (2003) Report of a Joint WHO/FAO Expert Consultation on Diet, Nutrition and the Prevention of Chronic Disease. WHO Technical Report Series, no. 916. Geneva: WHO.

11. Swinburn B \& Egger G (2002) Preventive strategies against weight gain and obesity. Obes Rev 3, 289-301.
12. Davison KK \& Birch LL (2001) Childhood overweight: a contextual model and recommendations for future research. Obes Rev 2, 159-171.

13. Egger G, Swinburn B \& Rossner S (2003) Dusting off the epidemiological triad: could it work with obesity? Obes Rev 4, 115-119.

14. Egger G \& Swinburn B (1997) An 'ecological' approach to the obesity pandemic. BMJ 315, 477-480.

15. Swinburn B, Egger G \& Raza F (1999) Dissecting obesogenic environments: the development and application of a framework for identifying and prioritizing environmental interventions for obesity. Prev Med 29, 563-570.

16. Comuzzie AG \& Allison DB (1998) The search for human obesity genes. Science 280, 1374-1377.

17. Deckelbaum RJ \& Williams CL (2001) Childhood obesity: the health issue. Obes Res 9, Suppl. 4, 239S-243S.

18. Sorensen TI, Holst C \& Stunkard AJ (1998) Adoption study of environmental modifications of the genetic influences on obesity. Int J Obes 22, 73-81.

19. Bouchard C \& Tremblay A (1997) Genetic influences on the response of body fat and fat distribution to positive and negative energy balances in human identical twins. $J$ Nutr 127, 943S-947S.

20. McDermott R, O'Dea K, Rowley K, Knight S \& Burgess P (1998) Beneficial impact of the homelands movement on health outcomes in central Australian aborigines. Aust N Z J Public Health 22, 653-658.

21. Popkin BM \& Udry JR (1998) Adolescent obesity increases significantly in second and third generation US immigrants: the National Longitudinal Study of Adolescent Health. J Nutr 128, 701-706.

22. Popkin BM (1998) The nutrition transition and its health implications in lower-income countries. Public Health Nutr 1, 5-21.

23. Drewnowski A \& Popkin BM (1997) The nutrition transition: new trends in the global diet. Nutr Rev 55, $31-43$.

24. World Health Organization (2006) Information sheet on obesity and overweight (WHO global strategy on diet, physical activity and health). http://www.who.int/ dietphysicalactivity/media/en/gsfs_obesity.pdf

25. Bhave S, Baydekar A \& Otiv M (2004) IAP national task force for childhood prevention of adult diseases: childhood obesity. Indian Pediatr 41, 559-575.

26. Wang Y, Monteiro C \& Popkin BM (2002) Trends of obesity and underweight in older children and adolescents in the United States, Brazil, China, and Russia. Am J Clin Nutr 75, 971-977.

27. Florencio TM, Ferreira HS, de Franca AP, Cavalcante JC \& Sawaya AL (2001) Obesity and undernutrition in a verylow-income population in the city of Maceio, northeastern Brazil. Br J Nutr 86, 277-284.

28. Allison DB, Matz PE, Pietrobelli A, Zannolli R \& Faith MS (2001) Genetic and environmental influences on obesity. In Primary and Secondary Preventive Nutrition, pp. 147-164 [A Bendich and RJ Deckelbaum, editors]. Totowa, NJ: Humana Press.

29. DiGuiseppi C, Roberts I \& Li L (1997) Influence of changing travel patterns on child death rates from injury: trend analysis. $B M J$ 314, 710-713.

30. World Health Organization (2004) Global Strategy on Diet, Physical Activity and Health: Obesity and Overweight. http://www.who.int/dietphysicalactivity/publications/facts/ obesity/en/

31. Parsons TJ, Power C, Logan S \& Summerbell CD (1999) Childhood predictors of adult obesity: a systematic review. Int J Obes 23, Suppl. 8, S1-S107. 
32. Matheson DM, Killen JD, Wang Y, Varady A \& Robinson TN (2004) Children's food consumption during television viewing. Am J Clin Nutr 79, 1088-1094.

33. Robinson TN, Hammer LD, Killen JD, Kraemer HC, Wilson DM, Hayward C \& Taylor CB (1993) Does television viewing increase obesity and reduce physical activity? Cross-sectional and longitudinal analyses among adolescent girls. Pediatrics 91, 273-280.

34. Maffeis C, Talamini G \& Tato L (1998) Influence of diet, physical activity and parents' obesity on children's adiposity: a four-year longitudinal study. Int J Obes 22, $758-764$.

35. Dietz WH Jr \& Gortmaker SL (1985) Do we fatten our children at the television set? Obesity and television viewing in children and adolescents. Pediatrics 75, $807-812$

36. Hernandez B, Gortmaker SL, Colditz GA, Peterson KE, Laird NM \& Parra-Cabrera S (1999) Association of obesity with physical activity, television programmes and other forms of video viewing among children in Mexico city. Int $J$ Obes 23, 845-854.

37. Hanley AJ, Harris SB, Gittelsohn J, Wolever TM, Saksvig B \& Zinman B (2000) Overweight among children and adolescents in a Native Canadian community: prevalence and associated factors. Am J Clin Nutr 71, 693-700.

38. Wake M, Hesketh K \& Waters E (2003) Television computer use and body mass index in Australian primary school children. J Paediatr Child Health 39, 130-134.

39. Reilly JJ, Armstrong J, Dorosty AR, Emmett PM, Ness A, Rogers K, Steer C \& Sherriff A for the Avon Longitudinal Study of Parents and Children Study Team (2005) Early life risk factors for obesity in childhood: cohort study. BMJ 330, 1357-1363.

40. Gortmaker SL, Must A, Sobol AM, Peterson K, Colditz GA \& Dietz WH (1996) Television viewing as a cause of increasing obesity among children in the United States, 1986-90. Arch Pediatr Adolesc Med 150, 356-362.

41. Phillips SM, Bandini LG, Naumova EN, Cyr H, Colclough S, Dietz WH \& Must A (2004) Energy-dense snack food intake in adolescence: longitudinal relationship to weight and fatness. Obes Res 12, 461-472.

42. Klesges RC, Shelton ML \& Klesges LM (1993) Effects of television on metabolic rate: potential implications for childhood obesity. Pediatrics 91, 281-286.

43. Reilly JJ \& McDowell ZC (2003) Physical activity interventions in the prevention and treatment of paediatric obesity: systematic review and critical appraisal. Proc Nutr Soc 62, 611-619.

44. Lewis MK \& Hill AJ (1998) Food advertising on British children's television: a content analysis and experimental study with nine-year olds. Int J Obes 22, 206-214.

45. Borzekowski DL \& Robinson TN (2001) The 30-second effect: an experiment revealing the impact of television commercials on food preferences of preschoolers. J Am Diet Assoc 101, 42-46.

46. Dietz WH (2001) The obesity epidemic in young children: reduce television viewing and promote playing. BMJ 322, $313-314$

47. Cavadini C, Siega-Riz AM \& Popkin BM (2000) US adolescent food intake trends from 1965 to 1996. Arch Dis Child 83, 18-24.

48. Harnack LJ, Jeffery RW \& Boutelle KN (2000) Temporal trends in energy intake in the United States: an ecologic perspective. Am J Clin Nutr 71, 1478-1484.

49. Takahashi E, Yoshida K, Sugimori H, Miyakawa M, Izuno T, Yamagami T \& Kagamimori S (1999) Influence factors on the development of obesity in 3-year-old children based on the Toyama study. Prev Med 28, 293-296.

50. Berteus Forslund H, Torgerson JS, Sjostrom L \& Lindroos AK (2005) Snacking frequency in relation to energy intake and food choices in obese men and women compared to a reference population. Int J Obes 29, 711-719.

51. Jebb SA (2005) Dietary strategies for the prevention of obesity. Proc Nutr Soc 64, 217-227.

52. Sturm R (2005) Childhood obesity - what we can learn from existing data on societal trends, part 2. Preventing Chronic Disease, vol. 2 no. 2. http://www.cdc.gov/pcd/ issues/2005/apr/04_0039.htm

53. Jahns L, Siega-Riz AM \& Popkin BM (2001) The increasing prevalence of snacking among US children from 1977 to 1996. J Pediatr 138, 493-498.

54. Marmonier C, Chapelot D \& Louis-Sylvestre J (2000) Effect of macronutrient content and energy density of snacks consumed in a satiety state on the onset of the next meal. Appetite 34, 161-168.

55. Johnstone AM, Shannon E, Whybrow S, Reid CA \& Stubbs RJ (2000) Altering the temporal distribution of energy intake with isoenergetically dense foods given as snacks does not affect total daily energy intake in normal-weight men. Br J Nutr 83, 7-14.

56. Blair AJ (1991) When are calories most fattening? Appetite 17, 161.

57. Barkeling B, Andersson I, Lindroos AK, Birkhed D \& Rossner S (2001) Intake of sweet foods and counts of cariogenic microorganisms in obese and normal-weight women. Eur J Clin Nutr 55, 850-855.

58. Wolfe WS, Campbell CC, Frongillo EA Jr, Haas JD \& Melnik TA (1994) Overweight schoolchildren in New York State: prevalence and characteristics. Am J Public Health 84, 807-813.

59. Siega-Riz AM, Popkin BM \& Carson T (1998) Trends in breakfast consumption for children in the United States from 1965 to 1991. Am J Clin Nutr 67, 748S-756S.

60. Thompson OM, Ballew C, Resnicow K, Gillespie C, Must A, Bandini LG, Cyr H \& Dietz WH (2006) Dietary pattern as a predictor of change in BMI z-score among girls. Int $J$ Obes 30, 176-182.

61. Ebbeling CB, Pawlak DB \& Ludwig DS (2002) Childhood obesity: public-health crisis, common sense cure. Lancet 360, 473-482.

62. Rolls BJ, Engell D \& Birch LL (2000) Serving portion size influences 5-year-old but not 3-year-old children's food intake. J Am Diet Assoc 100, 232-234.

63. McConahy KL, Smiciklas-Wright H, Birch LL, Mitchell DC \& Picciano MF (2002) Food portions are positively related to energy intake and body weight in early childhood. J Pediatr 140, 340-347.

64. Young LR \& Nestle M (2002) The contribution of expanding portion sizes to the US obesity epidemic. Am J Public Health 92, 246-249.

65. Gregory J \& Lowe S (2000) National Diet and Nutritional Survey: Young People Aged 4-18 Years, vol. 1: Report of the Diet and Nutrition Survey. London: The Stationery Office.

66. Tucker LA, Seljaas GT \& Hager RL (1997) Body fat percentage of children varies according to their diet. $J \mathrm{Am}$ Diet Assoc 97, 981-986.

67. Guillaume M, Lapidus L \& Lambert A (1998) Obesity and nutrition in children. The Belgian Luxembourg Child Study IV. Eur J Clin Nutr 52, 323-328.

68. McGloin AF, Livingstone MBE, Greene LC, Webb SE, Gibson JMA, Jebb SA, Cole TJ, Coward WA, Wright A \& 
Prentice AM (2002) Energy and fat intake in obese and lean children at varying risk of obesity. Int J Obes 26, 200-207.

69. Gibson SA (2000) Associations between energy density and macronutrient composition in the diets of pre-school children: sugars vs starch. Int J Obes 24, 633-638.

70. Robertson SM, Cullen KW, Baronowski J, Baronowski T, Shaouhua H \& de Moor C (1999) Factors related to adiposity among children aged 3-7y. J Am Diet Assoc 99, 939-943.

71. Magarey AM, Daniels LA, Bouton TJC \& Cockington RA (2001) Does fat intake predict adiposity in healthy children and adolescents aged 2-15y? A longitudinal analysis. Eur J Clin Nutr 55, 471-481.

72. St-Onge MP, Keller KL \& Heymsfield SB (2003) Changes in childhood food consumption patterns: a cause for concern in light of increasing body weights. Am J Clin Nutr 78, 1068-1073.

73. Bowman SA, Gortmaker SL, Ebbeling CB, Pereira MA \& Ludwig DS (2004) Effects of fast-food consumption on energy intake and diet quality among children in a national household survey. Pediatrics 113, 112-118.

74. Speiser PW, Rudolf MC, Anhalt $\mathrm{H}$ et al.; Obesity Consensus Working Group (2005) Childhood obesity. J Clin Endocrinol Metab 90, 1871-1887.

75. Prentice AM \& Jebb SA (2003) Fast foods, energy density and obesity: a possible mechanistic link. Obes Rev 4, $187-194$.

76. Ebbeling CB, Sinclair KB, Pereira MA, Garcia-Lago E, Feldman HA \& Ludwig DS (2004) Compensation for energy intake from fast food among overweight and lean adolescents. JAMA 291, 2828-2833.

77. Wilson JF (2000) Lunch eating behavior of preschool children. Effects of age, gender, and type of beverage served. Physiol Behav 70, 27-33.

78. Ludwig DS, Peterson KE \& Gortmaker SL (2001) Relation between consumption of sugar-sweetened drinks and childhood obesity: a prospective, observational analysis. Lancet 357, 505-508.

79. O’Connor TM, Yang S-J \& Nicklas TA (2006) Beverage intake among preschool children and its effect on weight status. Pediatrics 118, 1010-1018.

80. Fall CH, Osmond C, Barker DJ, Clark PM, Hales CN, Stirling Y \& Meade TW (1995) Fetal and infant growth and cardiovascular risk factors in women. BMJ 310, 428-432.

81. Curhan GC, Chertow GM, Willett WC, Spiegelman D, Colditz GA, Manson JE, Speizer FE \& Stampfer MJ (1996) Birth weight and adult hypertension and obesity in women. Circulation 94, 1310-1315.

82. Curhan GC, Willett WC, Rimm EB, Spiegelman D, Ascherio AL \& Stampfer MJ (1996) Birth weight and adult hypertension, diabetes mellitus, and obesity in US men. Circulation 94, 3246-3250.

83. Barker M, Robinson S, Osmond C \& Barker DJ (1997) Birth weight and body fat distribution in adolescent girls. Arch Dis Child 77, 381-383.

84. Stettler N, Zemel BS, Kumanyika S \& Stallings VA (2002) Infant weight gain and childhood overweight status in a multicenter, cohort study. Pediatrics 109, 194-199.

85. Sorensen HT, Sabroe S, Rothman KJ, Gillman M, Fischer P \& Sorensen TI (1997) Relation between weight and length at birth and body mass index in young adulthood: cohort study. BMJ 315, 1137.

86. Parsons TJ, Power C \& Manor O (2001) Fetal and early life growth and body mass index from birth to early adulthood in 1958 British cohort: longitudinal study. BMJ 323, $1331-1335$.
87. Whitaker RC \& Dietz WH (1998) Role of the prenatal environment in the development of obesity. J Pediatr 132, $768-776$.

88. Dabelea D, Hanson RL, Lindsay RS, Pettitt DJ, Imperatore G, Gabir MM, Roumain J, Bennett PH \& Knowler WC (2000) Intrauterine exposure to diabetes conveys risks for type 2 diabetes and obesity: a study of discordant sibships. Diabetes 49, 2208-2211.

89. Power C \& Jefferis BJ (2002) Fetal environment and subsequent obesity: a study of maternal smoking. Int $J$ Epidemiol 31, 413-419.

90. Von Kries R, Koletzko B, Sauerwald T, von Mutius E, Barnert D, Grunert V \& von Voss H (1999) Breast feeding and obesity: cross sectional study. BMJ 319, 147-150.

91. Grove KL, Sekhon HS, Brogan RS, Keller JA, Smith MS \& Spindel ER (2001) Chronic maternal nicotine exposure alters neuronal systems in the arcuate nucleus that regulate feeding behaviour in the newborn rhesus macaque. J Clin Endocrinol Metab 86, 5420-5426.

92. Von Kries R, Toschke AM, Koletzko B \& Slikker W Jr (2002) Maternal smoking during pregnancy and childhood obesity. Am J Epidemiol 156, 954-961.

93. Ravelli AC, van Der M, Osmond C, Barker DJ \& Bleker OP (1999) Obesity at the age of $50 \mathrm{y}$ in men and women exposed to famine prenatally. Am J Clin Nutr 70, 811-816.

94. Biro FM, McMahon RP, Striegel-Moore R, Crawford PB, Obarzanek E, Morrison JA, Barton BA \& Falkner F (2001) Impact of timing of pubertal maturation on growth in black and white female adolescents: The National Heart, Lung, and Blood Institute Growth and Health Study. J Pediatr 138, 636-643.

95. Kinra S, Baumer JH \& Davey Smith G (2005) Early growth and childhood obesity: a historical cohort study. Arch Dis Child 90, 1122-1127.

96. Ong KK, Ahmed ML, Emmett PM, Preece MA \& Dunger DB (2000) Association between postnatal catch-up growth and obesity in childhood: prospective cohort study. BMJ 320, 967-971.

97. Dorosty AR, Emmett PM, Cowin S \& Reilly JJ (2000) Factors associated with early adiposity rebound. ALSPAC Study Team. Pediatrics 105, 1115-1118.

98. Baird J, Fisher D, Lucas P, Kleijnen J, Roberts H \& Law C (2005) Being big or growing fast: systematic review of size and growth in infancy and later obesity. BMJ 331, 929-935.

99. Power C, Lake JK \& Cole TJ (1997) Body mass index and height from childhood to adulthood in the 1958 British born cohort. Am J Clin Nutr 66, 1094-1101.

100. Post GB \& Kemper HC (1993) Nutrient intake and biological maturation during adolescence. The Amsterdam growth and health longitudinal study. Eur J Clin Nutr 47, 400-408.

101. Gillman MW, Rifas-Shiman SL, Camargo CA Jr, Berkey CS, Frazier AL, Rockett HR, Field AE \& Colditz GA (2001) Risk of overweight among adolescents who were breastfed as infants. JAMA 285, 2461-2467.

102. Armstrong $\mathbf{J} \&$ Reilly JJ; Child Health Information Team (2002) Breastfeeding and lowering the risk of childhood obesity. Lancet 359, 2003-2004.

103. Dietz WH (2001) Breast feeding may help prevent childhood overweight. JAMA 285, 2506-2507.

104. Bergmann KE, Bergmann RL, Von Kries R, Bohm O, Richter R, Dudenhausen JW \& Wahn U (2003) Early determinants of childhood overweight and adiposity in a birth cohort study: role of breastfeeding. Int J Obes 27, $162-172$. 
105. Li L, Parsons TJ \& Power C (2003) Breast feeding and obesity in childhood: cross sectional study. BMJ 327, 904-905.

106. Victoria CG, Barros FC, Lima RC, Horta BL \& Wells J (2003) Anthropometry and body composition of 18 year old men according to duration of breast feeding. Birth cohort study from Brazil. BMJ 327, 901-904.

107. Clifford TJ (2003) Breast feeding and obesity. BMJ 327, 879-880.

108. Arenz S, Rucker R, Koletzko B \& von Kries R (2004) Breast-feeding and childhood obesity: a systematic review. Int J Obes 28, 1247-1256.

109. Wadsworth M, Marshall S, Hardy R \& Paul A (1999) Breast feeding and obesity. Relation may be accounted for by social factors. BMJ 319, 1576.

110. Hediger ML, Overpeck MD, Kuczmarski RJ \& Ruan WJ (2001) Association between infant breastfeeding and overweight in young children. JAMA 285, 2453-2460.

111. Poulton R \& Williams S (2001) Breastfeeding and risk of overweight. JAMA 286, 1449-1450.

112. Agostoni C, Scaglioni S, Ghisleni D, Verduci E, Giovannini M \& Riva E (2005) How much protein is safe? Int J Obes 29, Suppl. 2, S8-S13.

113. Agras WS, Kraemer HC, Berkowitz RI \& Hammer LD (1990) Influence of early feeding style on adiposity at 6 years of age. J Pediatr 116, 805-809.

114. Wells JC, Stanley M, Laidlaw AS, Day JM, Stafford M \& Davies PS (1997) Investigation of the relationship between infant temperament and later body composition. Int J Obes 21, 400-406.

115. Wardle J, Sanderson S, Guthrie CA, Rapoport L \& Plomin R (2002) Parental feeding style and the inter-generational transmission of obesity risk. Obes Res 10, 453-462.

116. Sekine M, Yamagami T, Handa K, Saito T, Nanri S, Kawaminami K, Tokui N, Yoshida K \& Kagamimori S (2002) A dose-response relationship between short sleeping hours and childhood obesity: results of the Toyama Birth Cohort Study. Child Care Health Dev 28, 163-170.

117. Agras WS, Hammer LD, McNicholas F \& Kraemer HC (2004) Risk factors for childhood overweight: a prospective study from birth to 9.5 years. J Pediatr 145, 20-25.

118. Padez C, Mourao I, Moreira P \& Rosado V (2005) Prevalence and risk factors for overweight and obesity in Portuguese children. Acta Paediatr 94, 1550-1557.

119. Wang H, Sekine M, Chen X, Kanayama H, Yamagami T \& Kagamimori S (2007) Sib-size, birth order and risk of overweight in junior high school students in Japan: results of the Toyama Birth Cohort Study. Prev Med 44, 45-51.

120. Lobstein $\mathrm{T}$, Baur L \& Uauy R for the IASO International Obesity Task Force (2004) Obesity in children and young people: a crisis in public health. Obes Rev 5, Suppl. 1, 4-104.

121. Strauss RS \& Knight J (1999) Influence of the home environment on the development of obesity in children. Pediatrics 103, e85.

122. Lissau I \& Sorensen TI (1994) Parental neglect during childhood and increased risk of obesity in young adulthood. Lancet 343, 324-327.

123. Davison KK \& Birch LL (2002) Obesogenic families: parents' physical activity and dietary intake patterns predict girls' risk of overweight. Int J Obes 26, 1186-1193.

124. Lake JK, Power C \& Cole TJ (1997) Child to adult BMI in the 1958 British birth cohort: associations with parental obesity. Arch Dis Child 77, 376-381.

125. Hood MY, Moore LL, Sundarajan-Ramamurti A, Singer M, Cupples LA \& Ellison RC (2000) Parental eating attitudes and the development of obesity in children. The Framingham Children's Study. Int J Obes 24, 1319-1325.

126. Wardle J, Guthrie C, Sanderson S, Birch L \& Plomin R (2001) Food and activity preferences in children of lean and obese parents. Int J Obes 25, 971-977.

127. Franks PW, Ravussin E, Hanson RL, Harper IT, Allison DB, Knowler WC, Tatarnni PA \& Salbe AD (2005) Habitual physical activity in children: the role of genes and the environment. Am J Clin Nutr 82, 901-908.

128. Danielzik S, Czerwinski-Mast M, Langnase K, Dilba B \& Muller MJ (2004) Parental overweight, socioeconomic status and high birth weight are the major determinants of overweight and obesity in 5-7 y-old children: baseline data of the Kiel Obesity Prevention Study (KOPS). Int J Obes $\mathbf{2 8}$, $1494-1502$.

129. Whitaker RC, Wright JA, Pepe MS, Seidel KD \& Dietz WH (1997) Predicting obesity in young adulthood from childhood and parental obesity. N Engl J Med 337, 869-873.

130. Wang Y, Ge K \& Popkin BM (2000) Tracking of body mass index from childhood to adolescence: a 6-y follow-up study in China. Am J Clin Nutr 72, 1018-1024.

131. Garn SM, Bailey SM \& Higgins IT (1976) Fatness similarities in adopted pairs. Am J Clin Nutr 29 , 1067-1068.

132. Etelson D, Brand DA, Patrick PA \& Shirali A (2003) Childhood obesity: do parents recognize this health risk? Obes Rev 11, 1362-1368.

133. Jeffery AN, Voss LD, Metcalf BS, Alba S \& Wilkin TJ (2005) Parents' awareness of overweight in themselves and their children: cross sectional study within a cohort (EarlyBird 21). BMJ 330, 23-24.

134. Strauss RS \& Pollack HA (2001) Epidemic increase in childhood overweight 1986-1998. JAMA 286, 2845-2848.

135. Booth ML, Wake M, Armstrong T, Chey T, Hesketh K \& Mathur S (2001) The epidemiology of overweight and obesity among Australian children and adolescents, 199597. Aust N Z J Public Health 25, 162-169.

136. Ogden CL, Flegal KM, Carroll MD \& Johnson CL (2002) Prevalence and trends in overweight among US children and adolescents, 1999-2000. JAMA 288, 1728-1732.

137. Whincup PH, Gilg JA, Papacosta O, Seymour C, Miller GJ, Alberti KG \& Cook DG (2002) Early evidence of ethnic differences in cardiovascular risk: cross sectional comparison of British South Asian and white children. BMJ 324, 635-641.

138. New SA \& Livingstone MB (2003) An investigation of the association between vending machine confectionery purchase frequency by schoolchildren in the UK and other dietary and lifestyle factors. Public Health Nutr 6, 497-504.

139. Belderson P, Harvey I, Kimbell R, O’Neill J, Russell J \& Barker ME (2003) Does breakfast-club attendance affect schoolchildren's nutrient intake? A study of dietary intake at three schools. Br J Nutr 90, 1003-1006.

140. Whincup PH, Owen CG, Sattar N \& Cook DG (2005) School dinners and markers of cardiovascular health and type 2 diabetes in 13-16 year olds: a cross sectional study. BMJ 331, 1060-1061.

141. Neumark-Sztainer D, French SA, Hannan PJ, Story M \& Fulkerson JA (2005) School lunch and snacking patterns among high school students: associations with school food environment and policies. Int J Behav Nutr Phys Act 2, 14.

142. Gould R, Russell J \& Barker ME (2006) School lunch menus and 11 to 12 year old children's food choice in three secondary schools in England - are the nutritional standards being met? Appetite 46, 86-92. 
143. Sahota P, Rudolf MC, Dixey R, Hill AJ, Barth JH \& Cade J (2001) Evaluation of implementation and effect of primary school based intervention to reduce risk factors for obesity. BMJ 323, 1027.

144. Sahota P, Rudolf MCJ, Dixey R, Hill AJ, Barth JH \& Cade J (2001) Randomised controlled trial of primary school based intervention to reduce risk factors for obesity. BMJ $\mathbf{3 2 3}$, 1029-1032.

145. Toh CM, Cutter J \& Chew SK (2002) School based intervention has reduced obesity in Singapore. BMJ 324, 427.

146. Robinson TN (1999) Reducing children's television viewing to prevent obesity: a randomized controlled trial. JAMA 282, $1561-1567$.

147. Metcalf BS, Voss LD \& Wilkin TJ (2002) Accelerometers identify inactive and potentially obese children (EarlyBird 3). Arch Dis Child 87, 166-167.

148. Mallam KM, Metcalf BS, Kirkby J, Voss LD \& Wilkin TJ (2003) Contribution of timetabled physical education to total physical activity in primary school children: cross sectional study. BMJ 327, 592-593.

149. Metcalf B, Voss L, Jeffery A, Perkins J \& Wilkin T (2004) Physical activity cost of the school run: impact on schoolchildren of being driven to school (EarlyBird 22). BMJ 329, 832-833.

150. Mo-Suwan L, Lebel L, Puetpaiboon A \& Junjana C (1999) School performance and weight status of children and young adolescents in a transitional society in Thailand. Int $J$ Obes 23, 272-277.

151. Timperio A, Salmon J, Telford A \& Crawford D (2005) Perceptions of local neighbourhood environments and their relationship to childhood overweight and obesity. Int J Obes 29, 170-175.

152. Burdette HL \& Whitaker RC (2005) A national study of neighbourhood safety, outdoor play, television viewing and obesity in preschool children. Pediatrics 116, 657-662.

153. Lumeng LC, Appugliese D, Cabral HJ, Bradley RH \& Zuckerman B (2006) Neighbourhood safety and overweight status in children. Arch Pediatr Adolesc Med 160, 25-31.

154. Hardy R, Wadsworth M \& Kuh D (2000) The influence of childhood weight and socioeconomic status on change in adult body mass index in a British national birth cohort. Int $J$ Obes Relat Metab Disord 24, 725-734.

155. Okasha M, McCarron P, McEwen J, Durnin J \& Davey Smith G (2003) Childhood social class and adulthood obesity: findings from the Glasgow Alumni Cohort. $J$ Epidemiol Comm Health 57, 508-509.

156. Mondena CWS, van Lentheb FJ \& Mackenbachb JP (2006) A simultaneous analysis of neighbourhood and childhood socio-economic environment with self-assessed health and health-related behaviours. Health Place 12, 394-403.

157. Power C \& Parsons T (2000) Nutritional and other influences in childhood as predictors of adult obesity. Proc Nutr Soc 59, 267-272.

158. Reidpath DD, Burns C, Garrard J, Mahoney M \& Townsend M (2002) An ecological study of the relationship between social and environmental determinants of obesity. Health Place 8, 141-145.

159. Stamatakis E, Primatesta P, Chinn S, Rona R \& Falascheti E (2005) Overweight and obesity trends from 1974 to 2003 in English children: what is the role of socioeconomic factors? Arch Dis Child 90, 999-1004.

160. Cecil JE, Watt P, Murrie IS, Wrieden W, Wallis DJ, Hetherington MM, Bolton-Smith C \& Palmer CN (2005) Childhood obesity and socioeconomic status: a novel role for height growth limitation. Int J Obes 29, 1199-1203.
161. Lamerz A, Kuepper-Nybelen J, Wehle C, Bruning N, TrostBrinkhues G, Brenner $\mathrm{H}$, Hebebrand $\mathrm{J} \&$ HerpertzDahlmann B (2005) Social class, parental education, and obesity prevalence in a study of six-year-old children in Germany. Int J Obes 29, 373-380.

162. Romon M, Duhamel A, Collinet N \& Weill J (2005) Influence of social class on time trends in BMI distribution in 5-year-old French children from 1989 to 1999. Int J Obes 29, 54-59.

163. Kinra S, Nelder RP \& Lewendon GJ (2000) Deprivation and childhood obesity: a cross sectional study of 20,973 children in Plymouth, United Kingdom. J Epidemiol Community Health 54, 456-460.

164. Dummer TJB, Gibbon MA, Hackett AF, Stratton G \& Taylor SR (2005) Is overweight and obesity in 9-10-yearold children in Liverpool related to deprivation and/or electoral ward when based on school attended? Public Health Nutr 8, 636-641.

165. Hakeem R (2001) Socio-economic differences in height and body mass index of children and adults living in urban areas of Karachi, Pakistan. Eur J Clin Nutr 55, 400-406.

166. Noor MI (2002) The nutrition and health transition in Malaysia. Public Health Nutr 5, 191-195.

167. Subramanian SV \& Smith GD (2006) Patterns, distribution, and determinants of under- and overnutrition: a populationbased study of women in India. Am J Clin Nutr 84, 633-640.

168. Coulston AM \& Johnson RK (2002) Sugar and sugars: myths and realities. J Am Diet Assoc 102, 351-353.

169. Cawley JH (2006) Markets and childhood obesity policy. Future Child 16, 69-88.

170. Tillotson JE (2004) America's obesity: conflicting public policies, industrial economic development, and unintended human consequences. Ann Rev Nutr 24, 617-643.

171. National Statistics (2006) United Kingdom Input-Output Analyses, 2006 Edition. http://www.statistics.gov.uk/inputoutput

172. Hill J \& Peters J (1998) Environmental contributions to the obesity epidemic. Science 280, 1371-1374.

173. Rolls B, Roe L, Meengs J \& Wall D (2004) Increasing the portion size of a sandwich increases energy intake. $J \mathrm{Am}$ Diet Assoc 104, 367-372.

174. Diliberti N, Bordi P, Conklin M, Roe L \& Rolls B (2004) Increased portion size leads to increased energy intake in a restaurant meal. Obes Res 12, 562-568.

175. Young LR \& Nestle M (2003) Expanding portion sizes in the US marketplace: implications for nutrition counselling. J Am Diet Assoc 103, 231-234.

176. Pelletier AL, Chang WW, Delzell JE Jr \& McCall JW (2004) Patients' understanding and use of snack food package nutrition labels. J Am Board Fam Pract 17, 319-323.

177. Geier AB, Rozin P \& Doros G (2006) Unit bias: a new heuristic that helps explain the effect of portion size on food intake. Psychol Sci 17, 521-525.

178. Schwartz J \& Byrd-Bredbenner C (2006) Portion distortion: typical portion sizes selected by young adults. $J$ Am Diet Assoc 106, 1412-1418.

179. Roefs A \& Jansen A (2004) The effect of information about fat content on food consumption in overweight/obese and lean people. Appetite 43, 319-322.

180. Wootan MG \& Osborn M (2006) Availability of nutrition information from chain restaurants in the United States. Am J Prev Med 30, 266-268.

181. Krukowski RA, Harvey-Berino J, Kolodinsky J, Narsana RT $\&$ Desisto TP (2006) Consumers may not use or understand 
calorie labeling in restaurants. J Am Diet Assoc 106, 917-920.

182. Clarke G, Eyre H \& Guy C (2002) Deriving indicators of access to food retail provision in British cities: studies of Cardiff, Leeds and Bradford. Urban Stud 39, 2041-2060.

183. Wrigley N (2002) 'Food deserts' in British cities: policy context and research priorities. Urban Stud 39, 2029-2040.

184. Whelan A, Wrigley N, Warm D \& Cannings E (2002) Life in a 'food desert'. Urban Stud 39, 2083-2100.

185. Wrigley N, Warm D, Margetts B \& Whelan A (2002) Assessing the impact of improved retail access on diet in a 'food desert' a preliminary report. Urban Stud 39, 2061-2082.

186. Sturm R \& Datar A (2005) Body mass index in elementary school children, metropolitan area food prices and food outlet density. Public Health 119, 1059-1068.

187. Pearson T, Russell J, Campbell MJ \& Barker ME (2005) Do 'food deserts' influence fruit and vegetable consumption? A cross-sectional study. Appetite 45, 195-197.

188. Winkler E, Turrell G \& Patterson C (2006) Does living in a disadvantaged area mean fewer opportunities to purchase fresh fruit and vegetables in the area? Findings from the Brisbane food study. Health Place 12, 306-319.

189. Cummins S \& MacIntyre S (2006) Food environments and obesity - neighbourhood or nation? Int J Epidemiol 35, $100-104$

190. Epstein LH, Handley EA, Dearing KK, Cho DD, Roemmich JN, Paluch RA, Raja SP \& Youngju SB (2006) Purchases of food in youth. Influence of price and income. Psychol Sci $\mathbf{1 7}, 82-89$.

191. Dwyer JT \& Ouyang CM (2000) What can industry do to facilitate dietary and behavioural changes? Br J Nutr 83, Suppl. 1, S173-S180.

192. Linn SE (2004) Food marketing to children in the context of a marketing maelstrom. J Public Health Policy 25, 367-378.

193. Neville L, Thomas M \& Bauman A (2005) Food advertising on Australian television: the extent of children's exposure. Health Promot Int 20, 105-112.

194. Connor SM (2006) Food-related advertising on preschool television: building brand recognition in young viewers. Pediatrics 118, 1478-1485.

195. Hoek J \& Gendall P (2006) Advertising and obesity: a behavioral perspective. J Health Comm 11, 409-423.
196. Lobstein T \& Dibb S (2005) Evidence of a possible link between obesogenic food advertising and child overweight. Obes Rev 6, 203-208.

197. Finkelstein EA, Ruhm CJ \& Kosa KM (2005) Economic causes and consequences of obesity. Annu Rev Public Health 26, 239-257.

198. Elliot A (2003) US food industry ensures that consumers are not told to eat less. BMJ 327, 1067.

199. Nestle M (2003) The ironic politics of obesity. Science 299, 781.

200. Rigby NJ, Kumanyika S \& James WPT (2004) Confronting the epidemic: the need for global solutions. J Public Health Policy 25, 418-434.

201. Weiss RI \& Smith JA (2004) Legislative approaches to the obesity epidemic. J Public Health Policy 25, 379-390.

202. Boseley S (2004) United States accused of sabotaging obesity strategy. Int J Health Serv 34, 553-554.

203. Daynard RA, Howard PT \& Wilking CL (2004) Private enforcement: litigation as a tool to prevent obesity. J Public Health Policy 25, 408-417.

204. Kelley B \& Smith JA (2004) Legal approaches to the obesity epidemic: an introduction. J Public Health Policy 25, $346-352$.

205. Nelson R (2004) "Cheeseburger Bill" protects food industry. Lancet 363, 954.

206. Davey RC (2004) The obesity epidemic: too much food for thought? Br J Sports Med 38, 360-363.

207. Hayne CL, Moran PA \& Ford MM (2004) Regulating environments to reduce obesity. J Public Health Policy 25, 391-407.

208. Butler D (2004) Health experts find obesity measures too lightweight. Nature 428, 244.

209. Finkelstein E, French S, Variyam JN \& Haines PS (2004) Pros and cons of proposed interventions to promote healthy eating. Am J Prev Med 27, Suppl. 3, 163-171.

210. Pratt M, Macera CA, Sallis JF, O’Donnell M \& Frank LD (2004) Economic interventions to promote physical activity: application of the SLOTH model. Am J Prev Med 27, Suppl. 3, 136-145.

211. Drewnowski A (2004) Obesity and the food environment: dietary energy density and diet costs. Am J Prev Med 27, Suppl. 3, 154-162. 